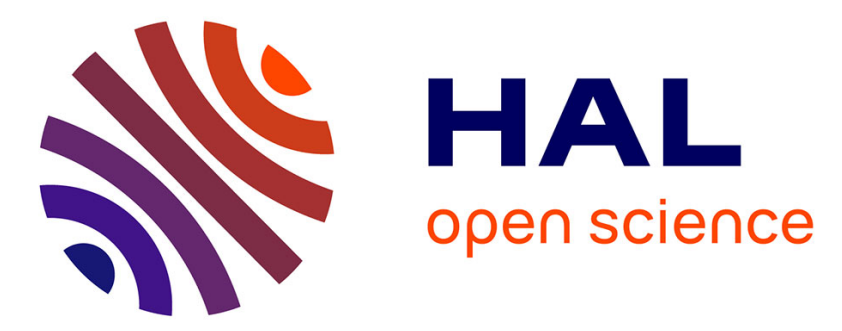

\title{
The polysemic meanings of couscous consumption in France
}

Amina Béji-Bécheur, Nacima Ourahhmoune, Nil Özçağlar-Toulouse

\section{To cite this version:}

Amina Béji-Bécheur, Nacima Ourahhmoune, Nil Özçağlar-Toulouse. The polysemic meanings of couscous consumption in France. Journal of Consumer Behaviour, 2014, 13, pp.196-203. 10.1002/cb.1478 . hal-01132487

\section{HAL Id: hal-01132487 \\ https://hal.science/hal-01132487}

Submitted on 17 Mar 2015

HAL is a multi-disciplinary open access archive for the deposit and dissemination of scientific research documents, whether they are published or not. The documents may come from teaching and research institutions in France or abroad, or from public or private research centers.
L'archive ouverte pluridisciplinaire HAL, est destinée au dépôt et à la diffusion de documents scientifiques de niveau recherche, publiés ou non, émanant des établissements d'enseignement et de recherche français ou étrangers, des laboratoires publics ou privés. 
Source : BÉJI-BÉCHEUR A., OURAHMOUNE N. and ÖZÇAĞLAR-TOULOUSE N. (2014), The polysemic meanings of couscous consumption in France, Journal of Consumer Behaviour, 13, 196-203.

\section{THE POLYSEMIC MEANINGS OF COUSCOUS CONSUMPTION IN FRANCE}

\section{Amina BEJI-BECHEUR}

Amina Béji-Bécheur is a professor of marketing at the Université Paris-Est and affiliated researcher at IRG, Blvd. Descartes Champs sur Marne, 77454, Marne-la-Vallée Cedex 2France; phone: (33) 1609579 69; e-mail: amina.becheur@u-pem.fr

\section{Nacima OURAHMOUNE}

Nacima Ourahmoune is a professor of marketing at Neoma Business School, Marketing, Consumption and Society research center, Reims Campus, 51100 France; phone: (33) 66466 11 43; e-mail: nacima.ourahmoune@neoma-bs.fr

\section{Nil ÖZÇAĞLAR-TOULOUSE*}

Nil Özçağlar-Toulouse is a professor of marketing at the Univ Lille Nord de France-SKEMA Business School and affiliated researcher at LSMRC, 1, Place Déliot-BP 381, 59020 Lille Cedex-France; phone: (33) 6184860 14; e-mail: nil.toulouse@univ-lille2.fr

\footnotetext{
* The three authors contributed equally to this project and should be considered co-first
} authors. 


\section{THE POLYSEMIC MEANINGS OF COUSCOUS CONSUMPTION IN FRANCE}

This article reflects on consumer representations of a typical southern Mediterranean dish that has remained a centerpiece of cultural encounters ever since it was developed in North Africa: couscous. France - a country whose own cuisine is world-renowned, yet which regularly ranks couscous as one of its top three favorite national dishes, and which hosts the largest North African population in Europe - seemed a fertile site for an investigation of the polysemic meanings attached to couscous, a nomad product embedded in socio-historical interrelationships on both shores of the Mediterranean. We found that consumers appropriate and adapt the product in ways that demonstrate some of the major features of Mediterranean relationships, with food as a vehicle for creative personal narratives. We emphasize the diversity of representations of couscous that help dissolve the usual northern/southern Mediterranean binaries in order to achieve a complex understanding of Mediterranean consumer behaviors.

Keywords: Couscous, Mediterranean food, southern Mediterranean, food culture 


\section{Introduction}

The Mediterranean basin is an area of extensive interactions around the Mare Nostrum. The region sees extensive migratory flows; memories, senses, images, tastes and aromas travel with each moving group or individual. Thus, a number of foreign dishes have become popular all around the Mediterranean as well as in Western Europe as a whole, and have been continuously re-appropriated: pizza, paella, doner kebab, couscous and many others (Cağlar 1995). These traditional dishes are symbols of socio-historical accounts and stand as cultural artifacts that link communities. They reduce geographical and psychosocial distances between diverse Mediterranean populations. As a contribution to broadening the scope of previous research that has tackled Mediterranean consumption, we have chosen to investigate a southern Mediterranean dish in the context of France in order to understand the diverse meanings that consumers of various cultural backgrounds identify with such a consumption. Through these narratives, we attain the complex dialectics of authenticity, place and hegemonies of taste that help de-binarize such cultural categories as northern/southern Mediterranean consumers, and illustrate nuances within the North African discourses, among others. This is to re-enact the plurality and diversity that guide the Mediterranean culture, where communitarianism and the ethnic grid of analysis that suits Anglo-Saxon approaches appear not to conform to Meridian Thought (Cassano, 1996). Rather, observing pluralist views within North African representations of couscous emphasizes a dialogic perspective.

\section{Conceptual Framework}

\section{The Mediterranean mindset and the Mediterraneanization of thought}

The Southern French mindset, as proposed by Cassano, is a specifically complex mindset. A complex mindset is 
necessarily a Southern French mindset, in other words a Mediterranean one. (Morin, 1998-1999, p. 46)

The Mediterranean mindset, as proposed by Morin, incorporates the notion of recognising the region's incredible legacy to humanity at various levels, from politics to poetry, from the sacred to the profane, and from conquest to integration. The Mediterranean basin is a land of contradictions par excellence, familiar with juggling opposites, and anyone reducing it to the stereotype of a hotbed of criminality or a spa resort runs the risk of missing out on the subtlety of its social interactions, the inventiveness of its lifestyle, and above all its visceral love of life, a simple concept immune to the acceleration of time in contemporary society. The Mediterranean mindset involves striving to penetrate the heart of the underlying societal structure without idealizing it or, conversely, viewing it as a model of decline. Thus, for Mediterraneans, the Mediterranean mindset is neither a question of veering towards ethnocentrism nor of systematically identifying onself as separate in juxtaposition with the English-speaking world. Nevertheless, investigating what the Mediterranean mindset can contribute towards elucidating the problems faced by consumer societies implies acknowledging that "The Northern English-speaking mindset is designed to accommodate and manage the prose of life, technical, practical and quantifiable problems. However, prose is a manner of surviving, whereas poetry is life itself: a Southern French mindset, as Cassano rightly says, incorporates the art of living and the poetry of life" (Morin, 1998-1999, p. 46). However, it is well known that in marketing, the North American mindset has imposed itself as the standard. Despite acknowledging the merits of certain thoughts, techniques and results of North American inspiration, the world on which these theories are founded is often different from the world experienced by Mediterranean people. The values it enshrines, the causes for which it rallies and the prism through which it views the world are not always 
reflected in the North's manner of functioning. Accordingly, marketing is an ensemble of techniques but not devoid of ideologies that cause unease among researchers engaged in initiatives such as Mediterranean marketing, Nordic marketing and more recently LatinoAmerican marketing. There is at least a desire to contribute an alternative viewpoint with regard to consumption phenomena, given that taking an interest in alternative pathways does not necessarily involve having specific cultural origins; it is enough to share the values of that culture.

The values of the Mediterranean and their contribution to marketing have already been highlighted in work dealing with authenticity (Cova, 2005; Badot and Graillot, 2006; Visconti, 2010), sense of proportion (Cova, 2004, Cova, 2005), conviviality and desire (Bucci, 2006), hedonistic pleasure and contemplation (Firat, 2005; Visconti, 2005), and branding and Mediterranean style (Dalli and Romani, 2011; Badot and Graillot, 2006; Visconti, 2005), as well as in regional contexts (Rémy, 2005; Ourahmoune and ÖzçaglarToulouse, 2012). Following these works, our research is aimed at understanding the representations of consumers of couscous in a French context. Although the majority of work to date has concentrated on consumption phenomena in southern Europe, for us it was crucial to extend the scope of the investigation to attempt to understand the experience of consumers, and in exploring the consumption of couscous - a north African dish - in France, whether or not the consumers had a personal connection with places in the south of the Mediterranean. Considering the homology drawn by Morin between the complex mindset and Cassano's southern French mindset, we will concentrate on "that which is woven together" (Morin's definition of complexity), which is so characteristic of the Mediterranean. From the history of couscous on both sides of the Mediterranean that de-binarize north-south rationales, the study reveals the complexity of the Mediterranean consumer. 


\section{The story of couscous, interwoven between the southern and northern Mediterranean}

To carry out our research, our focus is on a highly symbolic case in France: couscous, a dish of steamed semolina served with vegetables and meat. The main reason for choosing couscous was its special place as the third-favorite dish (TNS Sofres, 2012 ${ }^{1}$ ) in France, a country particularly renowned for its gastronomy (Ferguson, 2005; Hetzel, 2003). Secondly, couscous is an ancient dish that is nearly ubiquitous throughout the countries of the southern Mediterranean. It is a staple dish in Algeria, Morocco, Tunisia and Libya. Royalty in the kingdom of Granada knew of couscous, as mentioned in several thirteenth century books. It is also known to be an occasional dish in Egypt and Syria. Couscous is a traditional dish in the cuisine of Trapani, Sicily. In Rome, Barttolomeo Scappi’s culinary guide of 1570 describes a Moorish dish, succussu, in Tuscany (Dickie, 2008). One of the earliest references to couscous in France is in Brittany, yet it made an earlier appearance in Provence, where the traveler Jean-Jacques Bouchard wrote of eating it in Toulon in 1630.

Couscous was to become a significant part of modern French cuisine by way of the nineteenth century colonial route. The first French people to settle in the Maghreb were typically colonists of modest means who lived in rural areas (Hubert, 1995). Mediterranean migrants from Spain, Italy and Malta were also part of the European population in the north of Africa. At this point, pieds-noirs ${ }^{2}$ appear to have adopted local produce temporarily until they were able to establish means of producing the foods of their home countries, preserving their status as colonists (Tabois, 2005). During this period, the preparation of grain shifted from being a manual craft to an industrial operation, with the introduction of flourmills in Algeria (e.g., Maison Ricci in Blida in 1853 or Ferrero in Algiers in 1907). Following independence (between 1956 and 1962), the families of millers from North Africa typically settled in Marseille and developed the unexplored couscous manufacturing industry there.

\footnotetext{
${ }^{1} \mathrm{http}: / / \mathrm{www} . \mathrm{tns}-\mathrm{sofres} . c 0 \mathrm{~m} / \mathrm{etudes}-\mathrm{et}-$ points-de-vue/les-plats-preferes-des-francais-0

${ }^{2}$ Literally "black foots," a term used to refer to french nationals colonizing French Algeria until the end of the Algerian War in 1962.
} 
Since the end of the nineteenth century, there have been continuous waves of immigrants from Algeria to France. Couscous had been present in France since the nineteenth century as the staple food of the Kabyle people, a minority in Algeria who claim their Mediterranean origins over and above the Arabo-Islamic culture imposed on them, and who, behind Europeans, formed the vast majority of immigrants from the Maghreb. During the 1970s, in order to support French economic growth, North African immigration intensified. At the same time French law allowed for wives and children of immigrants to join them in France. This shift from the migration of male workers to that of families was a key factor in the enduring presence of couscous in France.

Today, couscous is available in traditional, canned, frozen and microwaveable forms. It has incorporated all the latest codes of contemporary consumption: organic, fair trade, prepackaged meals, takeaway, etc. It is served at canteens, restaurants, cafés, markets, and catered events. It can be found at social occasions: Republican couscous festival, 'Megafamily-couscous' against AIDS, Valentine's Day couscous, etc. It can even be the single unifying factor behind virtual communities, forums for couscous recipes, etc. In short, couscous is a Mediterranean symbol of cultural interpenetration.

\section{Methodology}

In order to investigate the consumer representations of this typically Mediterranean product in the contemporary French context, we carried out in-depth interviews with a varied sample of couscous consumers: 18 of Southern Mediterranean backgrounds some being French (French Algerians for instance is referred to as FR/A in the article), other being immigrants and also some regular tourists in France (Algerians (A), Moroccans (M) and Tunisians (T)) some of pied-noirs descent (PN)), and 10 interviews with French (FR) people who had no specific connection with the north of Africa. All informants were of diverse backgrounds, ages, 
genders and social statuses. In a second round of interviews, to obtain greater variation in consumer discourses regarding couscous consumption, we interviewed an additional four Algerians who travel to Paris on a regular basis. Subsequent to our first analysis, because Paris restaurants had frequently been mentioned by interviewees, we also interviewed two owners of restaurants in Paris that serve couscous.

The three authors of this paper have Mediterranean origins, but diverse backgrounds and relationships to couscous; the results represent their negotiated understanding of the data. Interviews were all transcribed. Each interview was first read in its entirety to gain a sense of the whole. Further readings were necessary to develop an integrated understanding of consumption meanings. We then applied inter-case analysis (Thompson, 1997); deepening our understanding of couscous consumption through such comparison. Indeed, each informant expresses his or herself in a different manner and their relations to couscous are all different. But some analogies exist at the subjective categories level, and thus we iteratively analysed our data between individual transcripts and our emerging understanding of the entire set of textual data (Thompson, 1997).

\section{The cultural polysemy of couscous}

Dialectics of authenticity

All interviewees agree couscous is a dish of North African origin. They also remark that when cooked by a native of North Africa, couscous is much tastier and, in a sense, "true couscous." So there is an essentializing dimension in the way respondents refer to a good couscous. Thus, couscous sold frozen or in tins appears to have a reputation as an unpleasant or even disgusting dish "stripped of any of its original culinary value" (Gilles, FR, 60). Industrialized couscous, however, is consumed by some informants of French origin, who acknowledge it is in no way an authentic couscous but rather the result of an assemblage, as is the case with 
other emblematic regional dishes such as paella, or blanquette de veau (veal in a white sauce). They are aware that (the) market(ing) provides them more with an interpretation of the dish rather than anything else.

I have made it on occasion, but I have to admit that I didn't serve it by itself - I'd bought some ready-prepared frozen vegetables and I made the sauce myself, added the meat and so on. It's a bit like paella, really - we're not purists. (Catherine, FR, 42) Informants with no link to a Mediterranean culture exhibit some technical knowledge with regard to how an authentic couscous should be, contrasting themselves with neophytes or unrefined consumers:

I don't think it looks nice, because tinned foods are really ugly, and I don't think it's hygienic either, because couscous needs to be dried, exposed to the air (Alex, FR, 28) Informants of non-North African origin also recognize and admire traditional knowhow in how to cook a real couscous:

When I came back from Morocco, I tried a couple of things, but the results were not my idea of couscous, so I gave up. I bought frozen vegetables, I made couscous, I added the meat, but to me it was a bit of a sacrilege, since in my head, couscous is something that takes a lot of work to make [...]If I had to make a real couscous I wouldn't know where to start. (Sophie, FR, 55)

The cooks I've seen making it were Algerian, Moroccan or Tunisian, and they made the best couscous I've ever eaten. (Gilles, FR, 60)

Informants of North African origin testify to this admiration via the cult of the mother, who is in charge of transmitting family and regional traditions. In keeping with the oral tradition, informants report that they learn by watching their mothers in the act of preparing it. One of the interviewees even filmed his mother: 
I filmed my mother while she was making the soup, and at every step I asked her to comment on what she was doing, so I have the recording on my PC. That way, whenever I want to make couscous, I put on the recording and follow it. For me, her food is the best. (Wael, FM, 23)

A tribute to the mother's couscous is generalized as the gold standard for this cooking practice.

You'll often hear people say that they prefer the couscous their mother makes and that's all there is to it. If you ask my husband, he'll tell you that he prefers the couscous his mother makes, and if you ask me, I'll say that I prefer the couscous my mother makes $[\ldots]$ for me, the real couscous is the one I make or that my mother makes. It's something I can't explain, because it's silly really. (Nissaf, FM, 33) Unsurprisingly, informants from a North African background similarly refused to recognize tinned and frozen couscous as couscous, with the same reaction; one informant described it as a "strange dish, not bad if you are really hungry but it has nothing to do with couscous" (Sofiane, A, 38). According to them, couscous must be prepared in the traditional manner, even if the recipe has been "Frenchified." Tinned couscous is seen as a sort of sacrilege, and almost a sign of contempt for one's culture of origin. The strictest rules seem to be reserved for dictating the list of ingredients used. Some Maghrebis insisted that the grain must come from their country of origin, and that ideally it should have been hand-rolled by their mother or a relative! They therefore insist on bringing back grain (up to $10 \mathrm{~kg}$ of it), olive oil or spices from their country when they go there on holiday. This is actually a practice that is very common among Mediterraneans who live far from their villages or towns: Italian grandmas' tomato sauce, Spanish ham and local olive oils are often given as presents before people fly back to the capital or abroad, signaling the strong attachment among Mediterraneans to local products. In a sense, "good" food a measure of distance from home. 
So, the semolina comes from Tunisia, the vegetables come from France; OK, as far as the meat goes, that depends, because when we make couscous just after coming back from Tunisia, we often bring back meat with us, because we like the produce over there ... My sister and I laugh about it every time, We're not the only ones, either - an aunt of mine in Germany does the same. They even have their own ice-box because they buy fish to bring back as well. French fish just doesn't taste the same. (Mounia, $\mathrm{T}, 27)$

However, although on first reading it would appear that everyone is in agreement in their strong bias against ready-made couscous and in favour of authentic "essentialized" couscous made by experts from products coming from as close to the original culture as possible, the concept of "authenticity" here needs to be nuanced.

One should not take consensus among respondents to prescribe a binary view that distinguishes whether the consumers are of Mediterranean origin or not. At the heart of the North African scope of the study, it should be noted that "authentic" couscous actually corresponds to the couscous of the family or regional culture of the informant. Although frozen and other industrial preparations are criticized (as part of a consensus not far removed from an effect of social desirability), fish couscous fell short of the approval of all respondents: "I think it's not bad-I tried it in Tunisia-but it's not the same as a good couscous from back home" (Ania, FR/A, 41). Similarly, couscous made with tomatoes according to the Jewish tradition of North Africa is seen as sacrilege by Algerians, and Kabyle couscous with "chicken and white sauce is just appalling" (Sofiane, A, 38) for a respondent from another region of Algeria. Thus, from one region of a given country to another, recipes change and tastes are formed accordingly, via an effect of socialization from childhood onwards that idealizes the couscous of one's own region as opposed to the couscous of other regions or other countries. 
Nevertheless, a contrary position is found among certain respondents, who admit that you can find good couscous in Paris no matter on which side of the Mediterranean your origins lie.

For couscous, you have to go to Paris (...) you can get couscous there that's better than the couscous I've eaten in Morocco. (Sophie, FR, 55)

I live in Algiers and I travel about 10 times a year to Paris, I haven't missed a couscous in a Kabyle bistro for 20 years, (...) there are some good ones around le Marais/Bastille (...) It is so good and I can get a glass of red wine with it, which is more difficult in Algiers (not everywhere serves alcohol) ... Couscous in Paris is an institution, it is totally different from the one I am used to at home, we would never serve merguez (North African sausage), chicken and mutton with couscous! You can only find it in France, and it is nevertheless delicious! (Moh, A, 62)

From this we can locate the micro in the macro in light of our section on the history of couscous in the French context. The dish was available in Paris, where over 30,000 Kabyle (a minority in Algeria) were living before Algerian independence (1962) and who over time managed to acquire over half of Parisian bistros. Although maintaining a typical French decor that is reminiscent of French bars and restaurants in Kabylia during colonization, they serve both couscous and all the traditional French bistro dishes. Couscous recipes have evolved in the Parisian context to propose assemblages absent from their culture of origin, certainly in order to appeal to a French clientele. Alcohol in particular is universally present, in contrast with certain other North African restaurants, with even a selection of North African wines. Indeed a Parisian couscous has arisen from this socio-historical context and draws many tourists visiting Paris to these couscoussières (French restaurants where couscous is a staple dish on the menu), where they can experience this particular type of consumption. 
To illuminate this phenomenon, interviews with owners of bistros serving couscous were conducted. One informant stressed the choice of maintaining the Kabyle culture as a reinforcement of his Mediterranean origin ("In 1980, I participated in the Kabyle cultural revolution ...", Mohand, FR/A, 49), namely through the decoration and menu he proposed in his restaurant. This stands for the phenomenon of Parisian couscoussières as a sort of panMediterranean culture.

Thus, Paella is found on a number of these menus, where couscous and its variants containing meat occupy such a prominent position for the sole reason that they typify a menu drawn up according to the strictest rules of French gastronomy, for a clientele composed chiefly of middle and senior managers. This reference to the overall Mediterranean experience is significant: it contributes towards placing the different waves of immigration from north or south of the Mediterranean on an equal footing. It undermines the distinctions between the categories of North Africa/southern Europe, Arabs/Berbers/Latins, Muslims/Christians, etc. by evoking a common identity springing from the same geographical basin. Presenting oneself appears to have found a third way in this approach, far removed from the mimetism of French provincial styles that involves renouncing one's culinary heritage or reconstituting a sumptuous orientalism that a restaurant owner describes as "fake ... because back home in Kabylia, we never took tea, we don't like gilded décor (we prefer silver), and like those restaurants in Algiers owned by a lot of Kabyles that look like seaside or mountain restaurants and have nothing of the Thousand and One Nights about them." (Mohand, FR/A, 49) This practice is aimed at capitalizing on one's local traditions as reactivated by economic development or by a cultural awakening. By using the resources of its adoptive country, it manifests in the same way that other culinary traditions advertise themselves commercially. This is voiced as the justification for hybrid restaurants where the Spanish, French, Italian, or other neighbouring culture with Kabylia is incorporated, to imbue the business with a 
multicultural appeal.. This mix of cultures calls to mind Mediterranean culture as a whole, which is located at the crossroads of three continents hosting countless distinctive and yet interconnected traditions cultures.

\section{Dialectics of the associative and the dissociative}

For most of the interviewees with a Mediterranean background, having couscous in a restaurant was a regrettable affair. Except for Kabyle tourists in Paris or recent North African immigrants who, in the absence of a family network, would end up feeling guilty eating couscous in a restaurant, finding an association but one that disassociates: "I went there in spite of myself with a friend for Aï; I don't know that many people there" (Sofiane, A, 38).

The touristic dimension of couscous, or the travel through "pluricultural" or exotic restaurants, is nevertheless present for people from both shores of the Mediterranean. One can consume "another culture" while remaining at home surrounded by familiar points of reference (Turgeon and Pastinelli, 2002).

The experience I have in Paris is also to do with the restaurant, the ambience, [...] The atmosphere is hushed and three waiters are dressed in djellabas, just as if the restaurant were in North Africa rather than in Paris. (Laure, FR, 28)

I've been to 404 in Paris, with its Berber décor, open kitchen, spices on display and the Moroccan chef. You feel like you're in Marrakesh, which for a Kabyle from Algeria is a change of scene! (Ania, FR/A, 40)

The range of Parisian couscous encompasses three ambiences: a Parisian bistro ambience, a chic neo-Marrakesh ambience and a popular "Oriental" ambience. Each of these atmospheres targets the differing needs of consumers and connects Mediterranean cultures together: ParisKabylia, Marrakesh-wealthy Paris, and middle-class Paris-mythified Orient. The restaurant identified in the quote above, which presents Berber/Moroccan cuisine in a high-class 
Marrakesh ambience, belongs to a Kabyle, who is offering an alternative product connected with exoticism and evasion, far removed from his culture of origin; this disassociates him from his group of origin but associates him with the group outside it.

Couscous is an experience to be consumed. Some interviewees are aware that the setting created in restaurants is artificial. Some seem to like it, whereas others feel manipulated:

It's a bit like a fairy-tale setting, kind of. You get to experience this atmosphere, with the décor and everything else, and you get treated like royalty, and for that couple of hours you're in Marrakech. There's something artificial about it all but that doesn't matter! It doesn't mean the product itself is any less good, but there is kind of, yeah, that's it - something artificial. (Fleur, FR, 27)

Yet the experience is extremely marginal for people from the southern Mediterranean region to eat couscous in restaurants because they associate couscous with being a meal at home, with family, and prominently with the figure of the mother, as described above.

I would never eat couscous in a restaurant. Couscous for me is at home. I wouldn't go out for dinner to have couscous. There's no place like home ... I'm not going to say that it's sacred and that it must only ever be eaten at home; it's a bit of a snap judgment ... maybe it's the image of a family all sitting down together. (Moufida, $\mathrm{F} / \mathrm{M}, 52)$

Couscous for interviewees with North African connections is first and foremost a dish that never needs to be paid for as it is a family dish, and thus is not eaten in restaurants. Here a Mediterranean notion of sharing and valuing home and clan atmospheres is coupled with values that are centered not around money but around exchanges, and which see cultural prowess as having a sense of hospitality: to share a couscous is to be associated with other people and to express one's attachment to the group. 
Couscous for us is the dish you share with people you value in life when you are sad and when you are happy, when your daughter is married or when your brother is buried, couscous in a sense is sacred, in these moments when we open the doors of our houses and feel the closeness and the satisfaction to feed as much people as possible. Couscous is also something we give to mosques and to charity organizations, it is not something we make money from; it is more to share. Of course, in Europe our cousins and relatives have opened restaurants and we are proud of their displaying our national dish and allowing the whole world to discover it. As I said earlier, I never miss a couscous in Paris, yet to me, couscous in my house it is something else. (Moh, A, 62) Following on this collective dimension of couscous, all interviewees of diverse origins relate to this dish as a "connector" of people. They described the ambience associated with the consumption of couscous as festive and convivial.

Couscous is like paella, I relate very much to the food in Spain for instance, it is freshly made, family cuisine, tasty and convivial, that is how I like couscous. (Sofiane, A, 38)

Couscous was the dish I served to my guests for my $40^{\text {th }}$ birthday, we had been cooking with my grandmother and mother all day long, and they talked about the atmosphere in Algeria back in the 1950s when they were still living there. In my family, couscous is definitely the dish for big fiestas, and for large gatherings of friends and family. (Lucile, $\mathrm{PN}, 41$ )

We all get together around this dish. That's the image that sticks in my mind couscous being always eaten by a lot of people gathered around. You never eat couscous on your own. You can't make it in small quantities; well, you can, but ... it's not like when you boil a single egg ... I don't know. You have to make at least half a kilo at a time. Maybe that's the image I have of it, subconsciously. (Moufida, F/M, 52) 


\section{Dialectics of frontiers and checkpoints}

As shown above there are various representations of couscous among interviewees from both shores of the Mediterranean. There is however a consensus on the federative, collective dimension of couscous, its required know-how idealized through the figure of the mother or through the concept of authentic couscous, and the diverse types of consumer experiences of eating couscous, both private and public, with a varied offer ranging from "authenticityseekers" to lovers of exoticism and travel.

Nonetheless, because the Mediterranean is such a space of clashes and communions, of diversity and difference, and because the Mediterranean food culture does not escape hierarchies of taste (Bourdieu, 1979), we have reported limits to the positive representations of the third most popular dish in France.

For French people, couscous made in France can also be associated with the northern African immigrant population, with the accompanying connotations of social disadvantage. Some people can only obtain couscous in Maghrebi districts (in restaurants in such areas). This makes it inaccessible due to social differences.

I wouldn't know which restaurant to choose, and I admit that as far as I know, the people I know or the restaurants I know are more upmarket restaurants, more towards the centre of Bordeaux, which are not restaurants in the Maghrebi area. ... [I go where] you find people like me, you know - middle-class people. It's less workingclass. (Sophie, FR, 55)

Some will characterize it as a popular dish lacking in refinement; it is mostly seen as a "dish of the people" or a "working-class dish." Although there is a selection of high-end restaurants that serve couscous in Paris, and although Morrocan cuisine for instance ranks among the three most refined cuisines in the world on a regular basis, it is still seen as a 
cheap, heavy dish that would not stand up to comparison with refined French cuisine. This marks a cultural distance and a contradiction within the discourse of informants that reduces the cultural distance by comparing couscous to "traditional" French dishes like magret de canard (fillet of duck), pot au feu (stewing beef) and cassoulet (sausage and beef hotpot). No, it doesn't come from anywhere else - people don't go around saying, "now that's a couscous" or "I can't wait for it to be couscous season again." No, it's a dish that has been assimilated and absorbed by France. It's no longer a luxury dish (in the sense of rare). (Gilles, FR, 60)

The taste of real couscous also is not typical of French cuisine (being spicy), which is not very well-adapted to French taste (Laure, FR, 28).

This last comment stems from an association of couscous with an Oriental culture; not all couscous is spicy and some recipes do utilise very common Mediterranean spices, but the imaginary of exoticism is strong, creating an inescapable cultural distance.

In turn, some informants from southern Mediterranean backgrounds also maintain this cultural distance. One informant shows he is aware of people in France perceiving couscous as being associated with lower-class immigration in France. To mark his disapproval, he reverses the discourse by emphasizing that eating couscous requires also good manners sometimes absent in France:

I do go to brasserie-type restaurants in areas of Paris that have become fashionable, where the trendy people eat, if you like. But I know they have a rather truncated vision of our culture, because their benchmarks are the suburbs, Barbès or something like that ... ignorance is basically everywhere, so what are you going to do? But when I see French people eat couscous, I think they have no refinement (laughs) ... you don't eat from all corners of your plate at once, otherwise it becomes a huge mess; you work your way through it methodically, so your plate stays tidy, by combining a bit of 
semolina and a few vegetables at a time, sometimes a little meat ... preferably with a spoon rather than a fork, because the grains should never fall back to your plate! (Moh, A, 62)

This is a sort of lesson in savoir-vivre by someone who reasserts his culture of origin, sensing it is not sufficiently valued in the French context. Another informant described being asked what he considered to be insulting questions about couscous when he moved from Algeria to France recently:

Several people mentioned that we do eat couscous with our hands in Algeria! I was shocked because I have never seen that in 37 years living there! It is as ignorant as asking me if there are lions running the streets of Algiers, a town 700 kilometers from Marseille, the same distance between Paris and Marseille. Or who are so surprised we have snow and ski resorts! I was very disappointed that people should get everything so mixed up, given the geographical but also cultural, historical proximity. I know in Morocco some people traditionally eat couscous by hand; I have never been there, but you would see this sense of superiority in people who ask me about it. (Sofiane, A, 38) These statements illustrate the reworking of cultural distances to keep one's identity alive. For North African informants, couscous is a way of displaying and experiencing their identity in the French context. There is a mixing-up between the origins of the dish and the origins of the consumers. For some, couscous represents their sense of belonging to a particular social class or a particular region, and the forms it takes differ greatly depending on the province of origin. It appears to represent a difference they are proud of, and is a very specific symbol of their territorial origins. Knowing and thus learning how to cook couscous therefore appears to be a collective responsibility. It is everyone's responsibility to make sure that the tradition is preserved, both in the country or region of origin and in the host country. For the 
interviewees, losing this knowledge means not being able to transmit it in turn, and thus losing the last bastion connecting them with their country of origin.

In a world of systematic deterritorialization, the populations of northern and southern Mediterraean countries, despite their involvement in the uprooting process (whether voluntarily or through necessity), are tempted to strive to soothe the pangs of that uprooting, sometimes via "ethnic replanting" (Touraine, 1997), recreating real or imaginary barriers that permeate south-south and north-south interactions within the basin. That said, as the examples provided throughout the findings have shown, couscous remains a cultural liaison as defined by Cassano (1996): a means of creating a bridge between the cultures of the Mediterranean.

\section{Discussion and conclusions}

Through these findings, we can perceive the universal nature of food, not to mention its ability to act as a mediator between cultures. Food is both material and symbolic, both individual and collective (Fischer, 1990). It is also reiterative, ephemeral and emotional. Food is functional and convivial; it is statutory, ostentatious, ritualized, sacred and associated with festive seasons. It has immediate or deferred effects on the health of the body and soul. It represents a unique link between inside and outside.

More precisely, our article is positioned as the next step after Bauman (2002) in terms of defining a distinction between "variety of cultures" and "cultural variety." One is essentialist and situates cultures as homogeneous and opposable entities, where individuals are nothing more than numbers, whereas the other is composed of complex, pluralist identities. Adopting this viewpoint thus equates to promoting diversity rather than difference. Far from promoting a binary interpretation of the north-south relationship in the Mediterranean, this research suggests the nuances and complexities permeating the 
representations of consumers of North African origin based on the diversity of opinions expressed, whereas North Africa is often seen as a monolithic block, as though a homogeneous southern Europe stood facing it. In particular, variations in viewpoints between Kabyles interviewed regarding assimilation into French culture, pride in Mediterranean heritage (verging on the anti-Arab Muslim) and opportunities to take steps towards an orientalization show the complexity of situating one's North African identity by way of consumption. This diversity has been nourishing the Mediterranean basin for millennia and is based less on a principle of difference than on a principle of complementary rivals. This is keenly felt in the competition between couscous recipes and in the affirmation of one's own region or clan as the makers of the best couscous.

A number of parallels are drawn here between respondents from the north and the south of the Mediterranean, for whom sharing a couscous is as much about enjoyment as it is about connections. Couscous is seen as a mediator of sharing but also of pleasure, conviviality and collective coexistence in what has been called a "hyperindividualist" society. This has led to a form of nostalgia arising amongst Mediterranean respondents. An acceleration in forms of deterritoriality, borne by the values of freedom, capitalism and idealized or even imaginary territorial anchor points forms the backdrop for the viewpoints expressed by informants. The interviewees retrace cultural distances to gain a stronger sense of belonging to a history, a group, etc.

Food in the modern context' has been sufficiently uprooted as to lack in authenticity or cultural identifiability and for that very reason becomes a problem of identity for the consumer who, not knowing what he is eating, suddenly does not know who he is. Yet, despite the upheavals caused by the revolution in wholesale distribution, the extreme variety of products on the market today and the difficulty in tracing their origins, Mediterranean people remain strongly attached to their culinary inheritance and its importance, if not in 
reality, at least in the collective imagination thanks to the close links that food practices have always woven into their history.

By increasing our knowledge of the various representations among consumers of the northern and southern Mediterranean, raising their preoccupation for authenticity, transmission, conviviality, and pleasure, we draw attention to the necessity of building a Mediterranean approach to marketing with consumers that represents the northern, southern and eastern shores of the Mare Nostrum. It is by emphasizing systematically this complex cultural dimension that cultural diversity (and not simply difference) can achieve a Mediterranean mindset, and a Mediterraneanization of thought (Morin, 1998-1999) in our field. 


\section{References}

Badot O., Graillot L. 2006. La différenciation symbolique des points de vente: Le cas de l'enseigne L'Occitane. Diriger et Entreprendre: 68-85.

Bauman Z. 2002. Society under siege. Polity: Cambridge.

Bourdieu P. 1979. Distinction: critique sociale du jugement. Seuil: Paris.

Bucci A. 2006. Appunti per un Marketing Mediterraneo. In Caru A., Cova B. (eds.), Marketing Mediterraneo: Tra Metafora e Territorio. Egea: Milan; 7-25.

Caglar A. 1995. McDoner: Doner Kebap and the Social Positioning Struggle of German Turks. In Costa J.A., Bamossy G.J. (eds), Marketing in a Multicultural World: Ethnicity, Nationalism and Cultural Identity. Sage Publications: London and New Delhi; 209-239.

Cassano F. 1998. La pensée méridienne. L’Aube : Paris.

Chaker S. 2013. Couscous: Sur l'étymologie du mot. [http://www.centrederechercheberbere.fr/tl_files/doc-pdf/couscous.pdf]

Cova B. 2005. Thinking of marketing in meridian terms. Marketing Theory 5(2): 205-214.

Dalli D., Romani S. 2012. Mediterranean shoes conquer the world. Global branding from local resources: the Camper base. In Penaloza L., Toulouse N., Visconti L. (eds.), Marketing Management: A cultural perspective. Routledge: London and New York; 4359.

Dickie J. 2008. Delizia! The Epic History of the Italians and Their Food. Free Press: New York.

Ferguson P.P. 2005. L'ostentation culinaire. Naissance du champ gastronomique. In Dubois J., Durand P., Winkin Y. (eds), Le Symbolique et le Social: La Réception internationale de la 
pensée de Pierre Bourdieu. Editions de l'Université de Liège collection Sociopolis: Liège; 93-101.

Firat F.A. 2004. Meridian thinking in Marketing? A comment on Cova. Marketing Theory. 5(2): 215-219.

Fischler C. 1990. L'Homnivore. Odile Jacob: Paris.

Hetzel P. 2003. Contemporary haute cuisine in France: When French chefs are paying their tributes to the past. In Sherry J., Brown S. (eds), Retroscapes rising: Time, space, and the market. Sharpe: New York; 238-52.

Hubert A. 1995. Destins transculturels. In Bessis S. (ed.), Mille et une bouches. Cuisines et identités culturelles. Autrement: Paris; 114-118.

Morin E. 1998-1999. Penser la Méditerranée et méditerranéiser la pensée. Confluences Méditerranée. 28: 33-47.

Ourahmoune N., Özçağlar-Toulouse N. 2012. Exogamous weddings and fashion in a rising consumer culture: Kabyle minority dynamics of structure and agency. Marketing Theory, 12(1): 81-99.

Rémy E. 2005. Régionalisme et consommation: Le cas de la Catalogne Nord. In Silva F., Carù A., Cova B. (eds.), Marketing Méditerranée et Postmodernité. Éditions Euromed: Marseille.

Tabois S. 2005. Cuisiner le passé, Souvenirs et pratiques culinaires des exilés Pieds Noirs. Diasporas, 7: 81-92.

Touraine A. 1997, Pourrons-nous vivre ensemble? Egaux et différents. Fayard: Paris. 
Visconti LM. 2010. Authentic brand narratives: co-constructed Mediterraneaness for l'Occitane brand, in Belk R.W. (ed.), Research in Consumer Behavior, Emerald, Bradford, 12: $231-260$.

Visconti L.M. 2005. L’individualisme postmoderne et la pensée Méditerranéenne: Oxymore et réconciliation par une approche de cultural-crossing. In Caru A., Cova B., Silva F. (eds.), Marketing Méditerranéen et Postmodernité, Euromed: Marseille; 127-148. 